\title{
Experimental and Analytical Performance of a Dual Brayton Power Conversion System
}

David S. Hervol and Maxwell Briggs

Analex Corporation, Brook Park, Ohio

A. Karl Owen

U.S. Army Research Laboratory, Glenn Research Center, Cleveland, Ohio

Thomas A. Lavelle

Glenn Research Center, Cleveland, Ohio 


\section{NASA STI Program . . . in Profile}

Since its founding, NASA has been dedicated to the advancement of aeronautics and space science. The NASA Scientific and Technical Information (STI) program plays a key part in helping NASA maintain this important role.

The NASA STI Program operates under the auspices of the Agency Chief Information Officer. It collects, organizes, provides for archiving, and disseminates NASA's STI. The NASA STI program provides access to the NASA Aeronautics and Space Database and its public interface, the NASA Technical Reports Server, thus providing one of the largest collections of aeronautical and space science STI in the world. Results are published in both non-NASA channels and by NASA in the NASA STI Report Series, which includes the following report types:

- TECHNICAL PUBLICATION. Reports of completed research or a major significant phase of research that present the results of NASA programs and include extensive data or theoretical analysis. Includes compilations of significant scientific and technical data and information deemed to be of continuing reference value. NASA counterpart of peer-reviewed formal professional papers but has less stringent limitations on manuscript length and extent of graphic presentations.

- TECHNICAL MEMORANDUM. Scientific and technical findings that are preliminary or of specialized interest, e.g., quick release reports, working papers, and bibliographies that contain minimal annotation. Does not contain extensive analysis.

- CONTRACTOR REPORT. Scientific and technical findings by NASA-sponsored contractors and grantees.

- CONFERENCE PUBLICATION. Collected papers from scientific and technical conferences, symposia, seminars, or other meetings sponsored or cosponsored by NASA.

- SPECIAL PUBLICATION. Scientific, technical, or historical information from NASA programs, projects, and missions, often concerned with subjects having substantial public interest.

- TECHNICAL TRANSLATION. Englishlanguage translations of foreign scientific and technical material pertinent to NASA's mission.

Specialized services also include creating custom thesauri, building customized databases, organizing and publishing research results.

For more information about the NASA STI program, see the following:

- Access the NASA STI program home page at http://www.sti.nasa.gov

- E-mail your question via the Internet to help@ sti.nasa.gov

- Fax your question to the NASA STI Help Desk at 301-621-0134

- Telephone the NASA STI Help Desk at 301-621-0390

- Write to: NASA Center for AeroSpace Information (CASI) 7115 Standard Drive Hanover, MD 21076-1320 


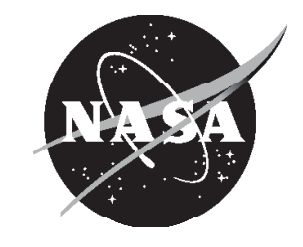

\section{Experimental and Analytical Performance of a Dual Brayton Power Conversion System}

David S. Hervol and Maxwell Briggs

Analex Corporation, Brook Park, Ohio

A. Karl Owen

U.S. Army Research Laboratory, Glenn Research Center, Cleveland, Ohio

Thomas A. Lavelle

Glenn Research Center, Cleveland, Ohio

Prepared for the

Sixth International Energy Conversion Engineering Conference (IECEC)

sponsored by the American Institute of Aeronautics and Astronautics

Cleveland, Ohio, July 28-30, 2008

National Aeronautics and

Space Administration

Glenn Research Center

Cleveland, Ohio 44135 


\section{Acknowledgments}

The work in this paper was performed for the Exploration Technology Development Program Fission Surface Power Project. The authors would like to thank Hal Weaver, Sandy Buettner, and Sig Lauge for their assistance with the implementation of the test rig.

Trade names and trademarks are used in this report for identification only. Their usage does not constitute an official endorsement, either expressed or implied, by the National Aeronautics and Space Administration.

Level of Review: This material has been technically reviewed by technical management.

Available from

NASA Center for Aerospace Information 7115 Standard Drive

Hanover, MD 21076-1320
National Technical Information Service 5285 Port Royal Road Springfield, VA 22161

Available electronically at http://gltrs.grc.nasa.gov 


\title{
Experimental and Analytical Performance of a Dual Brayton Power Conversion System
}

\author{
David S. Hervol and Maxwell Briggs \\ Analex Corporation \\ Brook Park, Ohio 44142 \\ A. Karl Owen \\ U.S. Army Research Laboratory \\ National Aeronautics and Space Administration \\ Glenn Research Center \\ Cleveland, Ohio 44135 \\ Thomas A. Lavelle \\ National Aeronautics and Space Administration \\ Glenn Research Center \\ Cleveland, Ohio 44135
}

\begin{abstract}
The interactions between two closed Brayton cycle (CBC) power conversion units (PCU) which share a common gas inventory and heat source have been studied experimentally using the Dual Brayton Power Conversion System (DBPCS) and analytically using the Closed-Cycle System Simulation (CCSS) computer code. Selected operating modes include steady-state operation at equal and unequal shaft speeds and various start-up scenarios. Equal shaft speed steady-state tests were conducted for heater exit temperatures of 840 to $950 \mathrm{~K}$ and speeds of 50 to $90 \mathrm{krpm}$, providing a system performance map. Unequal shaft speed steady-state testing over the same operating conditions shows that the power produced by each Brayton is sensitive to the operating conditions of the other due to redistribution of gas inventory. Startup scenarios show that starting the engines one at a time can dramatically reduce the required motoring energy. Although the DBPCS is not considered a flight-like system, these insights, as well as the operational experience gained from operating and modeling this system provide valuable information for the future development of Brayton systems.
\end{abstract}

\section{Introduction}

The closed Brayton cycle (CBC) is a candidate for dynamic power conversion in potential fission surface power systems proposed for long-term missions to the Moon and Mars (Refs. 1 and 2). CBC technology, for use in long-term space power generation systems, has been studied in depth at the Glenn Research Center using a single Brayton power conversion unit (PCU) (Refs. 3 and 4). However, the redundancy requirements of proposed fission surface power systems may require two Brayton PCUs to operate using a common gas inventory and a common heat source (Ref. 1). Coupling both Brayton loops through a common gas inventory causes the performance of each PCU to be affected by the operation of the other, especially when the engines operate at different shaft speeds. In order to study these interactions, the Dual Brayton Power Conversion System (DBPCS) was procured from Barber Nichols and delivered to the NASA Glenn Research Center in April of 2007. The DBPCS is a closed-cycle system which connects two otherwise independent Brayton PCUs through a single electrical heater with a common gas inventory. Preliminary testing of this system, as well as a more complete discussion of the hardware, is described by Johnson and Mason (2007) (Ref. 5). The focus of the current study is to establish a performance baseline for Brayton PCUs operating in a dual-loop configuration, quantify the interaction between the coupled PCUs, and qualitatively evaluate issues associated with start-up. 


\section{Method}

\section{Dual Brayton Power Conversion System Hardware Description}

The DBPCS test hardware is comprised of commercially available components that require only a few modifications (Figs. 1 and 2). Each PCU uses a Capstone open-loop micro-turbine engine with oilfree foil gas bearings providing shaft support. These engines were modified to accommodate closed-cycle operation using an inert gas working fluid (nitrogen) and a noncombustion heat source.

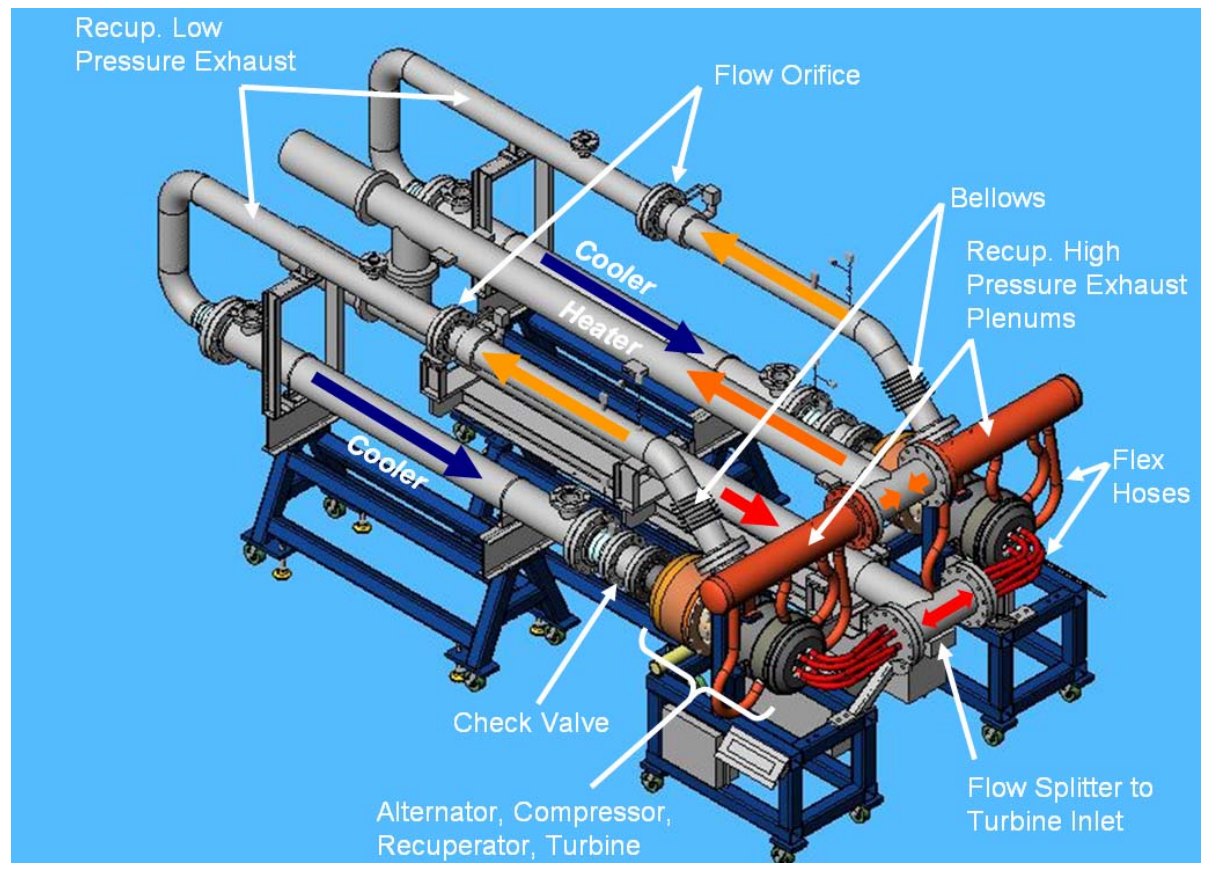

Figure 1.-DBPCS CAD Model.

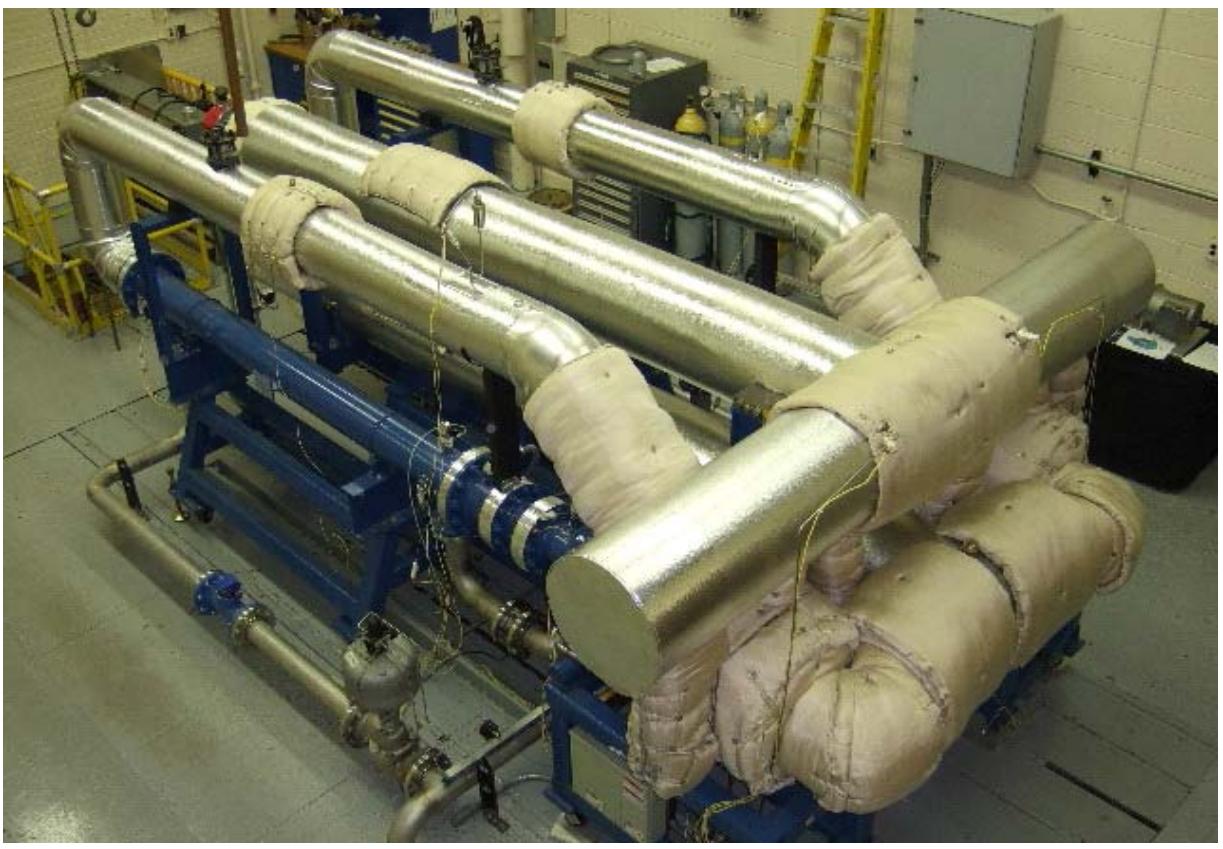

Figure 2.-DBPCS Test rig as installed at the NASA Glenn Research Center. 
The direct atmospheric exhaust of the open Brayton cycle is replaced by a gas-to-water cooler which redirects the flow to the compressor inlet, thus closing the Brayton loop. The combustors used for thermal input in the original engine design are replaced by a single shared electric resistance heater. This heater uses a 480 VAC power supply to provide a maximum of $180 \mathrm{~kW}$ of thermal input to both PCUs. A check valve, located at the gas cooler exit, prevents possible reverse flow resulting from a small back pressure that occurs when one of the engines is operational and the other is not.

The heater utilizes an industrial Proportional-Integral-Derivative (PID) controller that can provide either constant electrical power input or can control the heater exit temperature. The shaft speed of each engine is controlled using a parasitic load connected to the alternator. Any electrical power produced by the alternator is sent out to the commercial power grid. Loop temperatures and pressures are measured using capacitive pressure transducers and type K thermocouples. Data acquisition, shaft speed, and heater operation are controlled by National Instruments FieldPoint modules and LabView (National Instruments) software.

The Capstone design point for the turbomachinery is $1144 \mathrm{~K}$ hot-end temperature, $294 \mathrm{~K}$ cold-end temperature, and $96 \mathrm{krpm}$ shaft speed, with atmospheric intake and exhaust. At these conditions each PCU is expected to produce $30 \mathrm{kWe}$. Limitations on the modified DBPCS hardware resulted in maximum hot-end temperature, shaft speed, and compressor exit pressure of $950 \mathrm{~K}, 90 \mathrm{krpm}$, and $298 \mathrm{kPa}$, respectively. This limited the combined power output of both PCUs to about $20 \mathrm{kWe}$ and prevented the acquisition of a true maximum power point at high temperature. However, when the CCSS computer model, described below, is run at the Capstone recommended design condition it predicts a power output of $29 \mathrm{kWe}$ for each PCU. This suggests that power limitations are caused by constraints on the DBPCS hardware, rather than limitations specific to the dual-loop configuration.

\section{Closed Cycle System Simulation Model Description}

The CCSS is a closed Brayton cycle design and analysis tool written in the Numerical Propulsion System Simulation (NPSS) modeling environment (Ref. 6). The source code which forms the basis for the component characterizations used in the CCSS model originates from the NASA GRC in-house legacy Closed Cycle Engine Program (CCEP) and has been used in previous studies (Refs. 4, 7 to 10). CCSS models all of the major PCU components (ducts, recuperator, gas cooler, turbine, compressor, alternator, and heat source). It accounts for details such as bearing and windage losses, as well as thermal losses to the environment. A detailed explanation of the component models is presented by Johnson and Mason (2006) (Ref. 7) and Johnson and Hervol (2006) (Ref. 4) and a schematic of the model is shown in Figure 3.

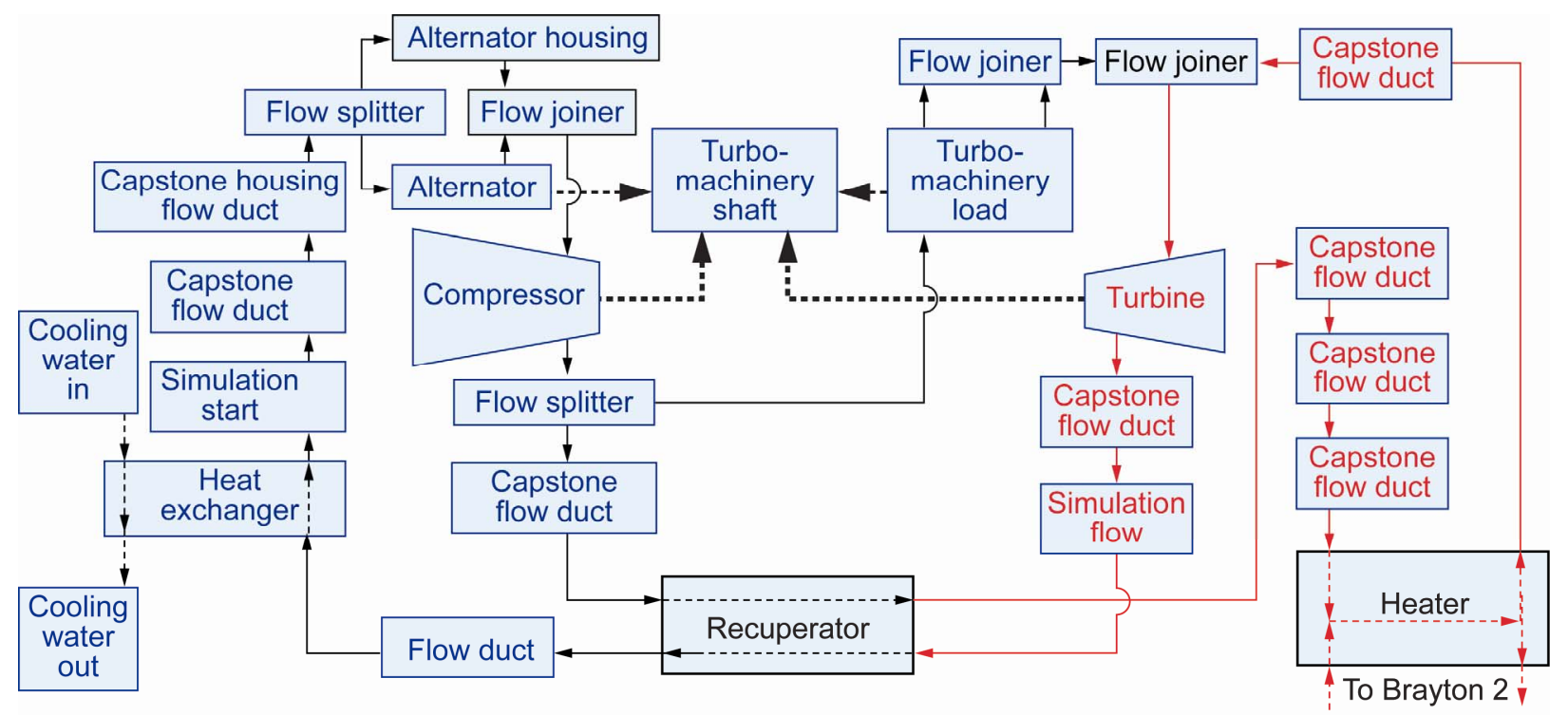

Figure 3.-CCSS Model Schematic. 
User inputs to the CCSS model include charge pressure (constant, $90 \mathrm{kPa}$ ), heater exit temperature ( 840 to $950 \mathrm{~K}$ ), water coolant temperature $(294 \mathrm{~K})$, coolant mass flow, and shaft speed (50 to $90 \mathrm{krpm}$ ). CCSS iteratively varies material temperatures, gas mass flow, and alternator load until the heater exit pressures of both PCUs equilibrate and the energy equation is balanced.

CCSS uses compressor and turbine map data to determine the efficiencies and pressure ratios of the turbomachinery at each operating condition. It is important to note that the maps used in this study were generated using the Centrifugal Compressor Off-Design Program (CCODP) and Radial Turbine OffDesign (RTOD) program, because compressor and turbine maps from the manufacturer were not available. These codes, developed in-house at the Glenn Research Center, are one-dimensional mean line representations using isentropic relationships and open literature correlations to predict compressor and turbine performance (Refs. 11 and 12). In order to improve the accuracy of these maps, relaxation factors were calculated for efficiencies and pressure ratios of both the compressor and the turbine. These relaxation factors were correlated with DBPCS pressure and temperature measurements at various operating conditions. The average value of these relaxation factors were then used as constant inputs for the current model. This process is essentially the same as the data reduction tasks that are performed when matching aircraft engine models with test stand data. In these cases, model parameters are varied to match known test data. These parameters are always empirical and not physical in nature. Adjusting them to take into account test data reflects a refinement of the preliminary values given by the in-house codes.

\section{Test Procedure}

\section{Reference Condition}

To ensure that PCU performance is consistent over the course of testing, it was necessary to establish a reference condition. This reference condition was chosen to be $950 \mathrm{~K}$ heater exit temperature (HET), $90 \mathrm{krpm}$ shaft speed, $306 \mathrm{~K}$ compressor inlet temperature, and $298 \mathrm{kPa}$ compressor outlet pressure. To begin each test, both PCUs are operated at this reference condition. The PCU loop temperatures and pressures resulting from operation at this reference condition are shown in Figure 4.

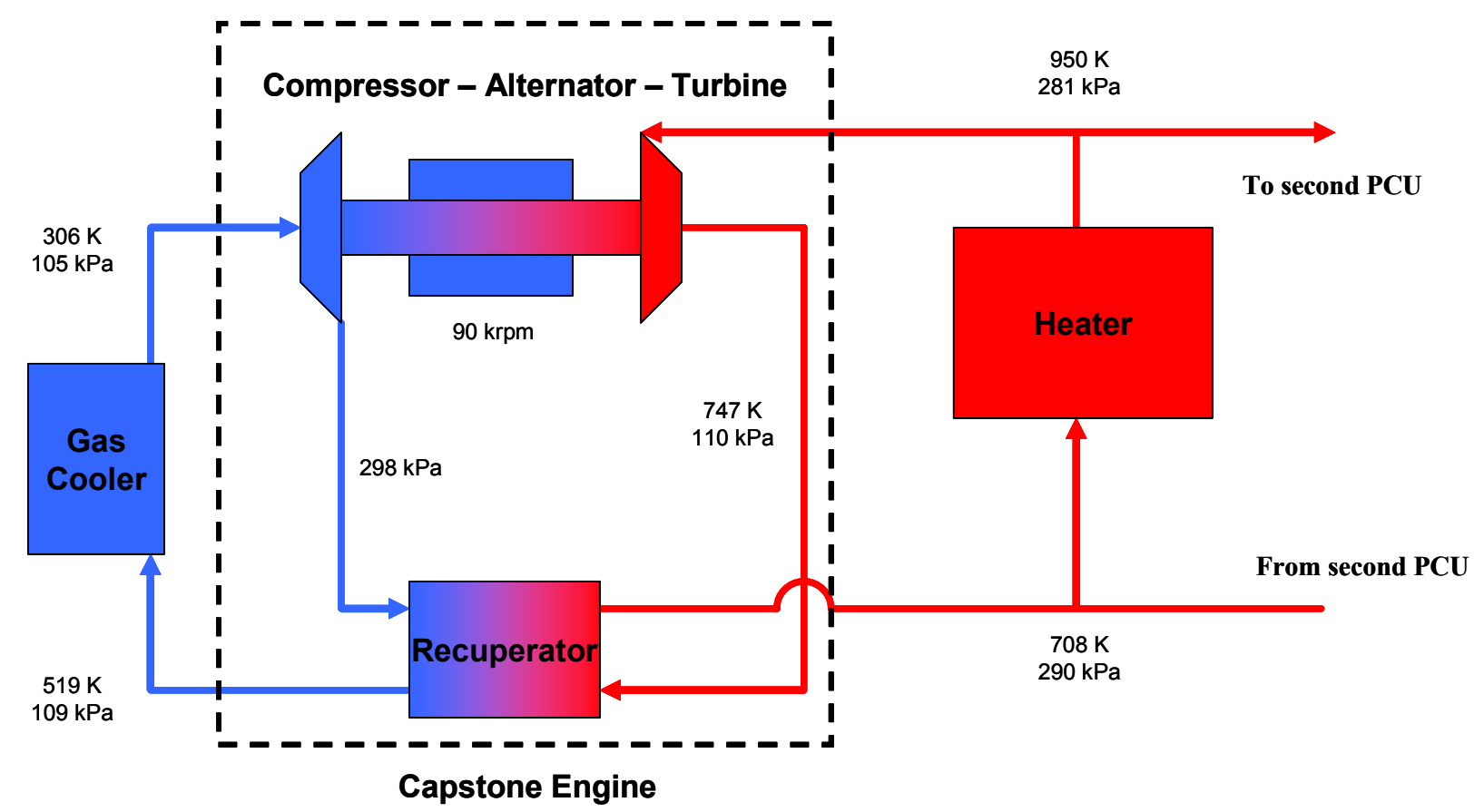

Figure 4.-Thermodynamic Data from the DBPCS Reference Condition.

(19.9 kWe total system output) 


\section{Equal Shaft Speed Steady Testing}

Data taken with both engines operating at the same shaft speed establishes the baseline performance of the DBPCS and aids in validating the CCSS model. To start these tests, the system is brought to the reference condition as described above. The system is then allowed to reach steady-state at the specified HET. Steady-state, as defined for this study is a condition at which no measured temperature changes more than $1 \mathrm{~K}$ over a $5 \mathrm{~min}$ period. Reaching this condition requires approximately $20 \mathrm{~min}$ for each $10 \mathrm{krpm}$ change in shaft speed. Once this condition is reached, steady-state data is collected and averaged over a 5 min period. Shaft speeds ranged from 50 to $90 \mathrm{krpm}$ while the HET ranged from 840 to $950 \mathrm{~K}$.

\section{Unequal Shaft Speed Testing}

Data taken with each engine operating at a different shaft speed shows the effect of gas inventory redistribution on PCU performance. To begin unequal shaft speed testing, the DBPCS is brought to the reference condition as described above. The system is then allowed to reach steady-state at the specified heater exit temperature with both engines operating at a shaft speed of $90 \mathrm{krpm}$. Maintaining a constant shaft speed on the first engine, the second engine shaft speed is decremented by $10 \mathrm{krpm}$. Speed is maintained until steady-state is reached. Once a steady-state data point is taken, the second engine is decremented another $10 \mathrm{krpm}$ and the process repeats until the second engine reaches $50 \mathrm{krpm}$. Once $50 \mathrm{krpm}$ is reached, the first engine is decremented $10 \mathrm{krpm}$ and the process repeats until both engines have been operated through the 50 to $90 \mathrm{krpm}$ speed range.

\section{Start-up Scenarios}

In order to identify tradeoffs associated with dual-loop CBC startups, several possible scenarios are tested. These tests include constant shaft speed and constant motoring power for both single-PCU and dualPCU start-up. Each scenario is run with heater power held constant with the HET allowed to vary. Each scenario begins with all DBPCS temperatures near room temperature and a charge pressure of $90 \mathrm{kPa}$ (the charge pressure that results in a $298 \mathrm{kPa}$ compressor exit pressure when operating at reference condition).

Prior to testing, $660 \mathrm{~K}$ was identified as the lowest temperature at which the DBPCS becomes power producing at any shaft speed. At this temperature, $34 \mathrm{krpm}$ was identified as the lowest speed at which the DBPCS generates power. This combination of HET and shaft speed is used as a common end point for all start-up tests.

During constant shaft speed start-up scenarios one or both PCU engines are spun at a constant speed of $34 \mathrm{krpm}$ while the heater power is held constant. The HET is allowed to increase until it reaches $660 \mathrm{~K}$, at which point the PCU(s) begins to produce power. During constant motoring power start-up scenarios, $2500 \mathrm{~W}$ of motoring power is supplied to one or both engines. As the HET rises, shaft speed is increased to maintain a constant motoring power until the HET reaches $660 \mathrm{~K}$. Once a HET of $660 \mathrm{~K}$ is reached the shaft speed is decreased to $34 \mathrm{krpm}$, and the $\mathrm{PCU}(\mathrm{s})$ begin to produce power. For all single-engine startup scenarios, after the first PCU begins to produce power, the HET is allowed to increase further until enough power is produced to motor the second engine $(\sim 500 \mathrm{~W})$. The second engine is then spun up to $25 \mathrm{krpm}$ (the minimum shaft speed) to verify that the entire system is producing power.

\section{Results}

\section{Equal Shaft Speed-Performance Map}

The DBPCS performance map is shown in Figure 5, along with the CCSS analytical performance map predictions. Open markers are used to indicate test data and closed markers indicate analytical predictions. For a given speed, power increases with increasing HET. For a given temperature there is an optimum speed that delivers maximum power. At a HET of $950 \mathrm{~K}$ this optimum speed lies outside of the tested range. 


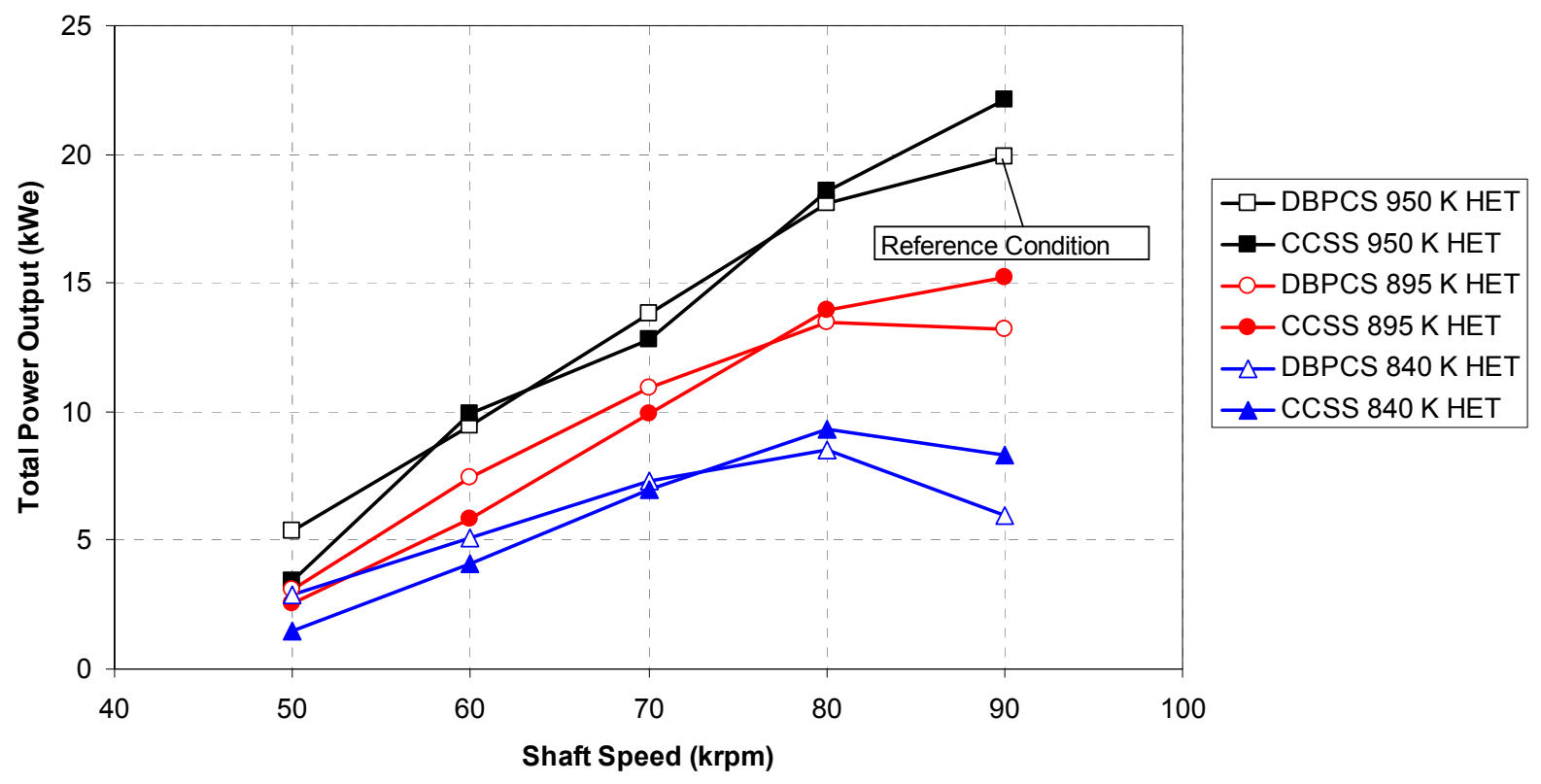

Figure 5.-DBPCS and CCSS Performance Map Results for Equal Shaft Speeds.

Analytical results are shown to be in good agreement with experimental data. The largest source of uncertainty in the analytical results comes from discrepancies between the turbomachinery maps used by CCSS and actual turbomachinery performance. Other areas of uncertainty include alternator windage losses, foil-bearing frictional losses, thermal losses to the environment, and measurement uncertainty. Despite these uncertainties CCSS is able to predict loop temperatures with an average error of 1 percent and pressures with an average error of 4 percent. The maximum errors in CCSS temperature and pressure predictions are 4 and 9 percent, respectively. These errors both occur at the most off-design condition of $840 \mathrm{~K}$ and $50 \mathrm{krpm}$. The computer generated turbomachinery maps tend to be the least accurate in this operating regime.

\section{Unequal Shaft Speed Operation Test Results}

The effect of coupling two Brayton PCUs through a common gas inventory can be seen in Figure 6, in which open markers indicate experimental data and closed markers indicate CCSS predictions. As the shaft speed of the variable speed PCU is decreased, the power output decreases, as expected. However, the power output of the constant speed PCU also decreases, despite being operated at the reference condition throughout the test. The reduction in power output is the result of a decrease in mass flow caused by redistribution of gas inventory from the high speed PCU to the low speed PCU.

\section{Constant Speed PCU Shaft Speed of $90 \mathrm{krpm}$ With Variable Speed PCU Shaft Speed (50 to $90 \mathrm{krpm})$}

The effect of the redistribution of gas inventory from the high speed PCU to the low speed PCU can be seen clearly in Figure 7. This figure compares the equal shaft speed performance map (single-engine) to the performance map of the variable speed PCU when the constant speed PCU is operated at 90 and $50 \mathrm{krpm}$. This comparison reveals an increase in power output of the variable speed PCU when it is operated as the low speed PCU, and a decrease in power output when it is operated as the high speed PCU. 


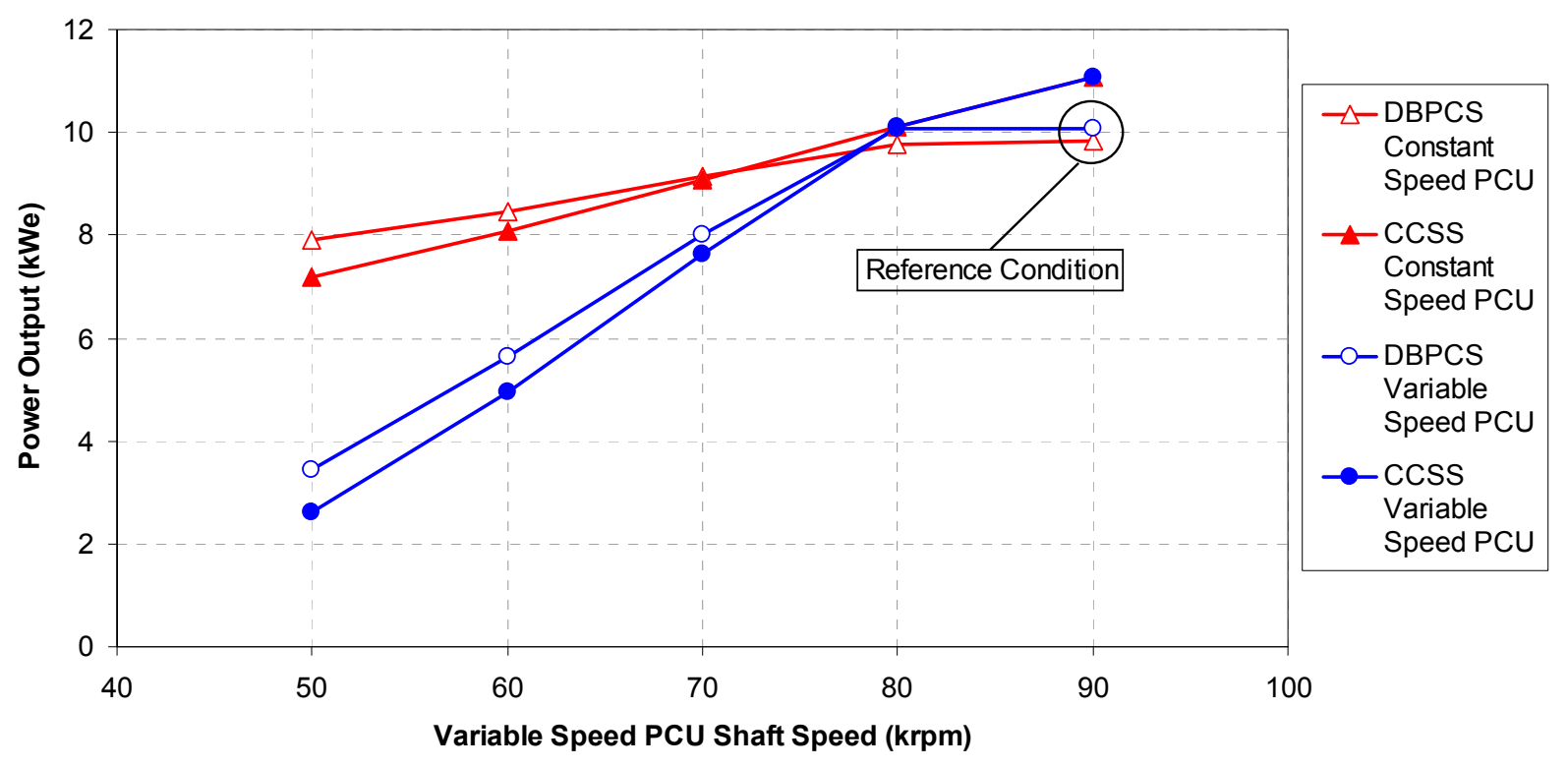

Figure 6.-PCU Power Output Versus Variable Speed PCU Shaft Speed at 950 K HET.

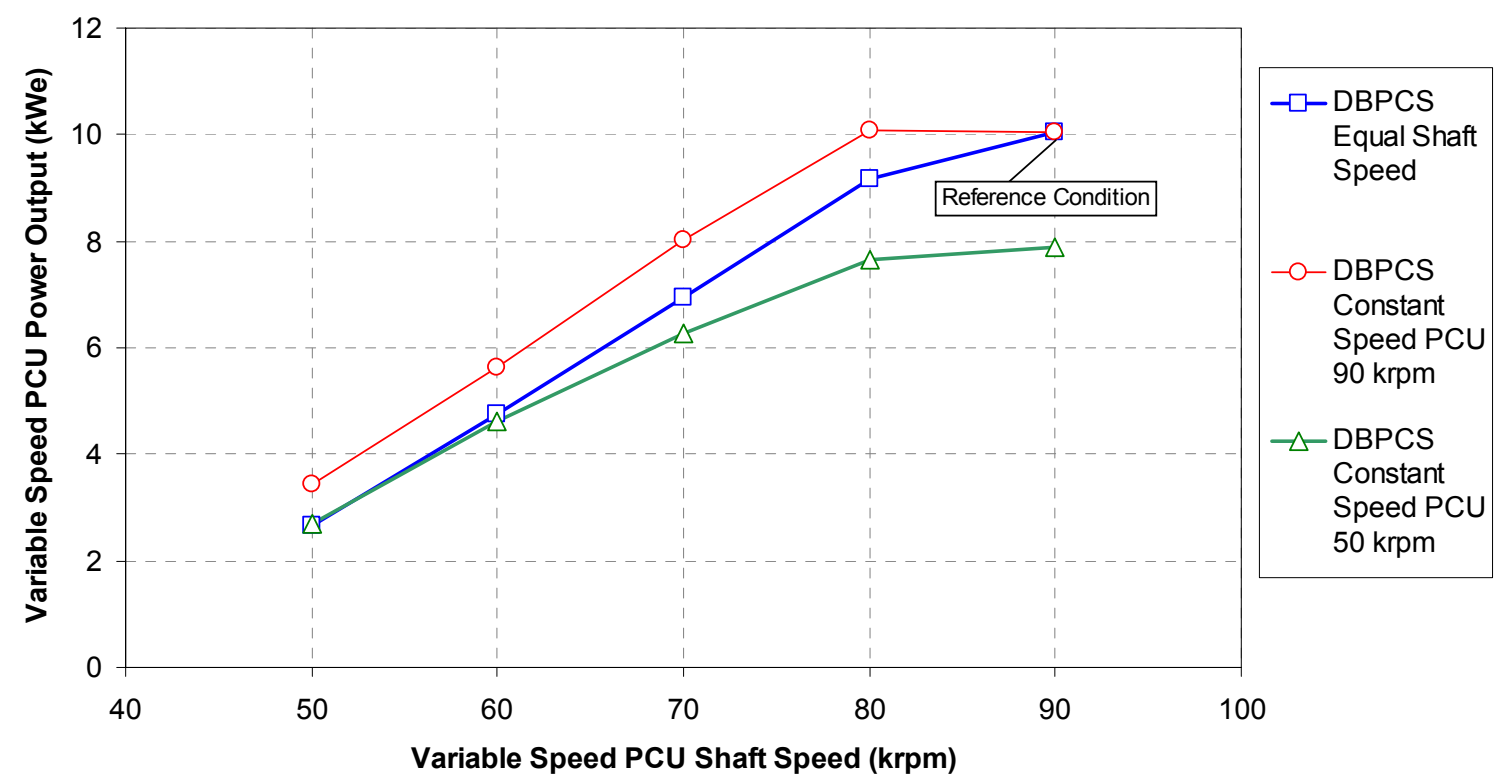

Figure 7.-Comparison of Equal Shaft Speed PCU Performance to Variable Speed PCU Performance Map. Variable Speed PCU functions as low speed PCU (90 krpm Constant Speed PCU Shaft Speed) (red). Variable Speed PCU functions as high speed PCU (50 krpm Constant Speed PCU Shaft Speed) (green).

It is difficult to directly measure the redistribution of gas inventory due to dramatic and nonlinear variations in gas density across components. However, it is possible to approximate gas inventory changes and make comparisons to equal speed operation using CCSS model predictions, (Table 1). The CCSS model confirms that the low speed PCU acts as an accumulator during unequal shaft speed operation. In addition to depriving the high speed PCU of working fluid it also removes gas from the heat source. 
TABLE 1.-CCSS PREDICTION OF GAS INVENTORY DISTRIBUTION AT $950 \mathrm{~K}$ AND $90 \mathrm{krpm}$ LEFT PCU SHAFT SPEED

\begin{tabular}{|c|c|c|c|c|}
\hline $\begin{array}{c}\text { Left shaft speed, } \\
\mathrm{krpm}\end{array}$ & $\begin{array}{c}\text { Right shaft speed, } \\
\mathrm{krpm}\end{array}$ & $\begin{array}{c}\text { Left loop gas mass, } \\
\text { percent }\end{array}$ & $\begin{array}{c}\text { Right loop gas mass, } \\
\text { percent }\end{array}$ & $\begin{array}{c}\text { Heater gas mass, } \\
\text { percent }\end{array}$ \\
\hline${ }^{\mathrm{a}} 90$ & ${ }^{\mathrm{a}} 90$ & 38.6 & 38.6 & 22.8 \\
\hline 90 & 80 & 36.3 & 42.5 & 21.2 \\
\hline 90 & 70 & 33.8 & 46.5 & 19.7 \\
\hline 90 & 60 & 31.4 & 50.5 & 18.1 \\
\hline 90 & 50 & 29.3 & 54.1 & 16.6 \\
\hline
\end{tabular}

${ }^{\mathrm{a}}$ Reference condition.

During practical operation of a dual-loop power conversion system for a fission surface power application both PCUs would likely operate at the same shaft speed except during start-up or after a failure. In either case, the PCU that acts as an accumulator will be nonoperational. Therefore, the redistribution of working fluid away from the operational PCU will cause a reduction in power while the accumulation of working fluid in the nonoperational PCU will provide no benefit. The increase in power of the low speed PCU is discussed only to support the argument that changes in power production from those seen during equal speed operation are caused by a redistribution of gas inventory.

\section{Start-up Scenarios}

During start-up, the power required to motor the engine(s) is recorded until the system becomes power producing. Example test data from a dual start test using $180 \mathrm{~kW}$ heater power is seen in Figure 8. The motoring power is then integrated numerically with respect to time to determine the total energy requirement for that start-up scenario. The CCSS model was not used in predicting startup scenarios.

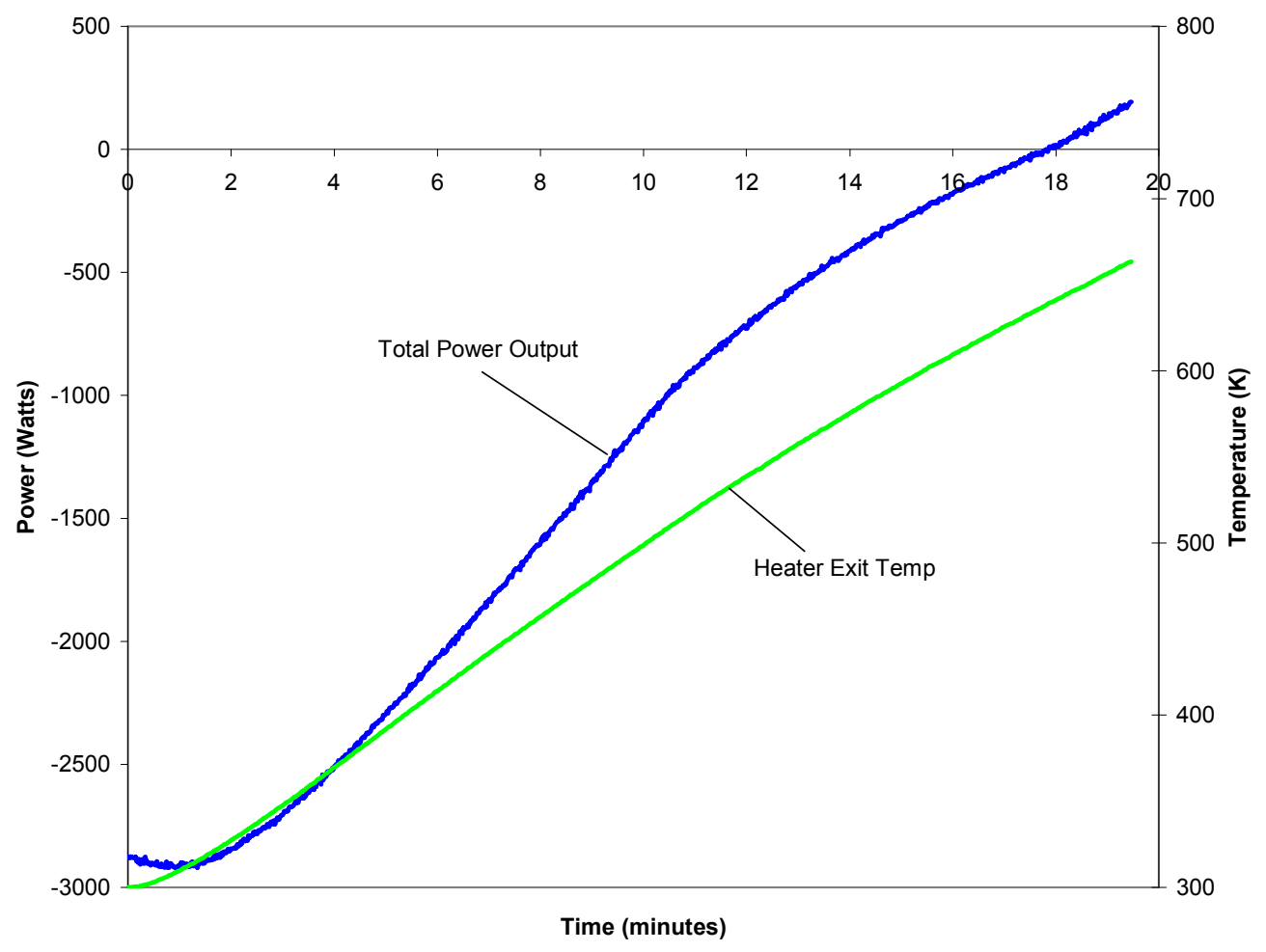

Figure 8.-Dual Start-180 kW Heater Power Constant Speed (34 krpm) Start-up. 
Table 2 summarizes the results of DBPCS start-up testing. Constant speed scenarios consistently require less motoring energy than constant motoring power scenarios for a given heater power. Also, starting one PCU, allowing it to reach a power producing condition, and using it to start the second PCU dramatically reduces the required motoring energy, for a given heater power. However, maximum heater sheath temperature limitations prevent single PCU start-up scenarios from being run at high heater powers. The ability to run at high heater power shortens the time required to become power producing, thus reducing the required motoring energy. As a result, the scenario that required the least motoring energy in this study was the dual-PCU constant speed start-up scenario, run at maximum heater power $(180 \mathrm{~kW})$. The single-PCU constant speed start-up scenario has a comparable motoring energy requirement despite being run at less than half of the heater power $(72 \mathrm{~kW})$, which reinforces the motoring energy benefits of single-PCU start-up scenarios.

TABLE 2.-BREAKEVEN MOTORING START TEST RESULTS

\begin{tabular}{|c|c|c|c|c|c|}
\hline $\begin{array}{l}\text { Heater electric } \\
\text { power, } \\
\text { kW }\end{array}$ & Motoring condition & $\begin{array}{l}\text { Motoring energy } \\
\text { required, } \\
\text { kw-hr }\end{array}$ & $\begin{array}{c}\text { Time to 1st PCU } \\
\text { breakeven, } \\
\text { min }\end{array}$ & $\begin{array}{l}\text { Time to system } \\
\text { breakeven, } \\
\text { min }\end{array}$ & $\begin{array}{c}\text { Max heater sheath } \\
\text { temperature, } \\
\mathrm{K}\end{array}$ \\
\hline 90 & $\begin{array}{l}\text { Dual PCU start-up- } \\
\text { constant motoring } \\
\text { power, } 2500 \mathrm{~W} / \text { side }\end{array}$ & 3.7 & 46 & 46 & 703 \\
\hline 180 & $\begin{array}{l}\text { Dual PCU start-up- } \\
\text { constant motoring } \\
\text { power, } 2500 \mathrm{~W} / \text { side }\end{array}$ & 1.4 & 20 & 20 & 754 \\
\hline 90 & $\begin{array}{l}\text { Dual PCU start-up- } \\
\text { constant speed, } \\
34 \mathrm{krpm}\end{array}$ & 0.8 & 38 & 38 & 762 \\
\hline 180 & $\begin{array}{l}\text { Dual PCU start-up- } \\
\text { constant speed, } \\
34 \mathrm{krpm}\end{array}$ & 0.4 & 18 & 18 & 895 \\
\hline 90 & $\begin{array}{l}\text { Single PCU start-up- } \\
\text { constant motoring } \\
\text { power, } 2500 \mathrm{~W}\end{array}$ & 1.6 & 39 & 66 & 924 \\
\hline 72 & $\begin{array}{l}\text { Single PCU start-up- } \\
\text { constant speed, } \\
34 \mathrm{krpm}\end{array}$ & 0.5 & 52 & 61 & 939 \\
\hline
\end{tabular}

The maximum heater sheath temperature limitations which prevent single-PCU start-up scenarios from being tested at high heater powers are specific to the DBPCS hardware. However, the trade-off between providing adequate cooling to the heat source and minimizing the required motoring energy will have to be considered in potential fission surface power systems.

\section{Conclusions}

Baseline performance of this unique system was characterized by measuring total power output at various heater exit temperatures with both PCU engines running at equal shaft speeds. The redistribution of gas inventory within this coupled system was studied by measuring individual PCU power output while the PCU engines were operated at unequal shaft speeds. Several different start-up scenarios were run to identify tradeoffs associated with dual-loop startup. The steady-state behavior of the system was successfully modeled using the CCSS computer code. The results of these tests, as well as operational experience gained from running and modeling a dual-loop system will assist in the design of future dualloop $\mathrm{CBC}$ power conversion systems. 


\section{References}

1. Mason, L.S., “A Power Conversion Concept for the Jupiter Icy Moons Orbiter,” NASA/TM-2003212596, September 2003.

2. Mason, L.S., "A Comparison of Fission Power System Options for Lunar and Mars Surface Applications," Space Technology and Applications International Forum-2006, edited by M.S. El-Genk, American Institute of Physics, Albuquerque, NM, 2006, pp. 270-280.

3. Hervol, D.S, Mason, L.S., and Birchenough, A., "Experimental Results From a 2 kW Brayton Power Conversion Unit," in proceedings of Space Technology and Applications International Forum (STAIF-2003), edited by M.S. El-Genk, AIP Conference Proceedings 665, Melville, NY, 2003, pp. 621-628.

4. Johnson, P.K., and Hervol, D.S., "Experimental Validation of a Closed Brayton Cycle System Transient Simulation," Proceedings of the Space Technology and Applications International Forum, edited by M. El-Genk, American Institute of Physics, vol. 813, New York, 2006, pp. 673-681; also NASA/CR—2006-214239, March 2006.

5. Johnson, P.K., and Mason, L.S., "Initial Results of a Dual Closed-Brayton-Cycle Power Conversion System," NASA/TM-2007-214981, December 2007.

6. Lavelle, T.M., Khandelwal, S.C., and Owen, A.K., "Intermediate Fidelity Closed Brayton Cycle Power Conversion Model," NASA/TM-2006-213993.

7. Johnson, P.K., and Mason, L.S. "Performance and Operational Characteristics for a Dual Brayton Space Power System With Common Gas Inventory," Proceedings of the 4th International Energy Conversion Engineering Conference, vol. 4, AIAA, Sajn Diego, CA, 2006; also NASA/TM-2006214393, November 2006.

8. Barrett, M.J., and Johnson, P.K., "Performance and Mass Modeling Subtleties in Closed-BraytonCycle Space Power Systems," Proceedings of the 3rd International Energy Conversion Engineering Conference, vol. 3, AIAA, Washington, DC, 2005, pp. 1596-1607; also NASA/TM-2005-213985, November 2005.

9. Barrett, M.J., and Reid, B.M., "System Mass Variation and Entropy Generation in 100-kWe ClosedBrayton-Cycle Space Power Systems," Proceedings of the Space Technology and Applications International Forum, edited by M. El-Genk, American Institute of Physics, vol. 699, New York, 2004, pp. 445-452; also NASA/TM-2004-212741, January, 2004.

10. Johnson, P.K., and Mason, L.S. "Design and Off-Design Performance of $100 \mathrm{kWe}-\mathrm{Class}$ Brayton Power Conversion Systems," Proceedings of the Space Technology and Applications International Forum, edited by M. El-Genk, American Institute of Physics, vol. 746, New York, 2005, pp. 711718; also NASA/TM-2005-213626, June 2005.

11. Wood, J.R. "Computer Code for Off-Design Performance Prediction of Centrifugal Compressors," Unpublished User Documentation, Lewis Research Center, 1995.

12. Meitner, P.L. and Glassman, A.J. "Computer Code for Off-Design Performance Analysis of Radial Inflow Turbines With Rotor Blade Sweep,” NASA TP-2199, 1983. 


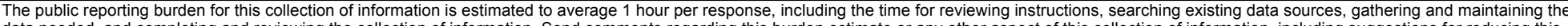

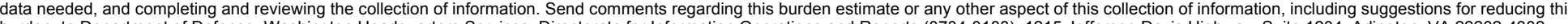

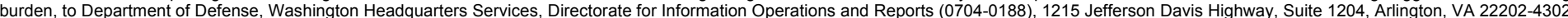

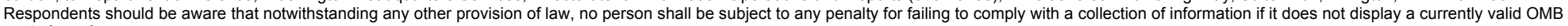
control number.

COntrol number.

\section{REPORT DATE $(D D-M M-Y Y Y Y)$ \\ 2. REPORT TYPE \\ 3. DATES COVERED (From - To)}

01-02-2009

\section{TITLE AND SUBTITLE}

Technical Memorandum

Experimental and Analytical Performance of a Dual Brayton Power Conversion System

\section{5a. CONTRACT NUMBER}

5b. GRANT NUMBER

5c. PROGRAM ELEMENT NUMBER

\section{AUTHOR(S)}

Hervol, David, S.; Briggs, Maxwell; Owen, A., Karl; Lavelle, Thomas, A.

\section{5d. PROJECT NUMBER}

5e. TASK NUMBER

5f. WORK UNIT NUMBER

WBS 463169.04.03.04.02.01

\section{PERFORMING ORGANIZATION NAME(S) AND ADDRESS(ES)}

National Aeronautics and Space Administration

8. PERFORMING ORGANIZATION

REPORT NUMBER

John H. Glenn Research Center at Lewis Field

E-16807

Cleveland, Ohio 44135-3191

\section{SPONSORING/MONITORING AGENCY NAME(S) AND ADDRESS(ES)}

National Aeronautics and Space Administration

Washington, DC 20546-0001

10. SPONSORING/MONITORS
ACRONYM(S)
NASA; AIAA
11. SPONSORING/MONITORING
REPORT NUMBER
NASA/TM-2009-215511; AIAA-2008-
5735

\section{DISTRIBUTION/AVAILABILITY STATEMENT}

Unclassified-Unlimited

Subject Categories: 02 and 44

Available electronically at http://gltrs.grc.nasa.gov

This publication is available from the NASA Center for AeroSpace Information, 301-621-0390

\section{SUPPLEMENTARY NOTES}

\section{ABSTRACT}

The interactions between two closed Brayton cycle (CBC) power conversion units (PCU) which share a common gas inventory and heat source have been studied experimentally using the Dual Brayton Power Conversion System (DBPCS) and analytically using the ClosedCycle System Simulation (CCSS) computer code. Selected operating modes include steady-state operation at equal and unequal shaft speeds and various start-up scenarios. Equal shaft speed steady-state tests were conducted for heater exit temperatures of 840 to $950 \mathrm{~K}$ and speeds of 50 to $90 \mathrm{krpm}$, providing a system performance map. Unequal shaft speed steady-state testing over the same operating conditions shows that the power produced by each Brayton is sensitive to the operating conditions of the other due to redistribution of gas inventory. Startup scenarios show that starting the engines one at a time can dramatically reduce the required motoring energy. Although the DBPCS is not considered a flight-like system, these insights, as well as the operational experience gained from operating and modeling this system provide valuable information for the future development of Brayton systems.

\section{SUBJECT TERMS}

Energy conversion; Centrifugal compressors; Turbocompressors; Turbine instruments; Gas cooled reactors

\begin{tabular}{|c|c|c|c|c|}
\hline \multicolumn{3}{|c|}{ 16. SECURITY CLASSIFICATION OF: } & \multirow{2}{*}{$\begin{array}{l}\text { 17. LIMITATION OF } \\
\text { ABSTRACT } \\
\text { UU }\end{array}$} & \multirow{2}{*}{$\begin{array}{l}\text { 18. NUMBER } \\
\text { OF } \\
\text { PAGES } \\
16\end{array}$} \\
\hline $\begin{array}{l}\text { a. REPORT } \\
\text { U }\end{array}$ & $\begin{array}{l}\text { b. ABSTRACT } \\
U\end{array}$ & $\begin{array}{l}\text { c. THIS } \\
\text { PAGE } \\
\text { U }\end{array}$ & & \\
\hline
\end{tabular}

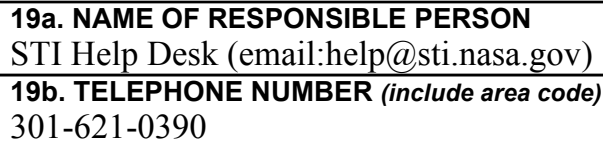



